\title{
Form of Mandate as a Message in Folklore
}

\author{
Yusni Khairul Amri ${ }^{1}$, Dian Marisha Putri ${ }^{2}$, Bambang Panca Saputra ${ }^{3}$ \\ 1,3Universitas Muhammadiyah Sumatera Utara, Indonesia \\ ${ }^{2}$ University of Sumatera, Indonesia \\ Email: amri_lubis@ymail.com,caca_milano@yahoo.com, bambangpanca@umsu.ac.id
}

Abstract: Folklore often reflects the creativity of traditional communities while still holding fast to tradition as a manifestation of creativity that lives and is passed down from generation to generation. Thus, folklore stories remain oriented towards values as a mandate with local ethnic content. The mandate as a value has always been a measure in determining truth and justice that comes from the content of religion, logic, and norms that apply in society. Interpreting values in folklore by interpreting a behavioral tendency that starts from psychological symptoms such as: desires, motives, attitudes, needs, and beliefs, so that the values of folklore can be used as parametric values of education, religion. The form of the mandate as values in folklore stories can educate in taking lessons as well as role models that are worthy of being guided and then used as examples of bad and bad behavior not to be imitated like a mother's love for her child who sincerely and selflessly forgives her child. The mandate as a value in Karo folklore is biased such as: a) the mandate to forgive, b) the mandate to obey parents, $c$ ) the mandate to keep promises, $d$ ) the mandate to be patient, e) the mandate not to be arrogant and arrogant, $f$ ) the mandate to be humble.

Keywords: Mandate; Folklore; Ethnic

\section{Introduction}

Folklore area Karo by general reflects the ethnic and cultural community of the Karo region. That matterreflected through various values of folklore that reflect the Karo ethnic community as a creative society. The characteristic bias of the Karo people is still very strong in maintaining various ethnic cultures. People who live in rural areas still live traditionally while still holding fast to their ancestral traditions. This is a bias from the manifestation of creativity that is alive and has been passed down from generation to generation until now.

Thus, folklore stories remain oriented towards local ethnic values, so that ethnic values

become an indicator to determine regional culture which is the assessment of truth or religiosity while still being sourced from customary and cultural norms in the Karo ethnic community.

The interpretation of the forms of mandate on ethnic values in Karo regional folklore as a general ethnic bias on behavior that shows psychological phenomena of ethnic

communities including: mandate as a value to work hard, be positive, be honest, work together, help, keep promises, listen advice, be obedient and obedient to parents, should not be arrogant or arrogant to always be humble, it becomes an ethnic bias in the folklore of the Karo area. According to Amri (2020:11) folklore narratives are usually done when: a) going to sleep; b) working in the fields; c) Chatting; d) Datu treats the sick. Folklore as a cultural heritage needs to be studied so that cultural values can be understood as messages that can be understood. Ethnic folklore as a biased expression that crystallizes thoughts, experiences, as well as a reflection of the feelings of the ethnic community. Folklore as a local identity is an ethnic collective pride as the fruit of wisdom and social intelligence.

Folklore has provided valuable lessons about the nature of trustworthiness that can be trusted by carrying out the message of people who are entrusted to do well. By holding one's 
trust, one is responsible for carrying out a mandate that one has. On the other hand, the nature of trust is treason or not carried out properly, it will result in a lot of badness. Promises must be kept because they promise we owe to fulfill them. The attitude of trust as a cultural character of the Karo people must be biased towards trust as well as not to betray that trust. The values of amanah education as a folklore bias reflect that the Karo people must be firm to keep their promises.

\section{Review of Literature}

Amanah holds someone's trust to be guarded, protected, and implemented. Amanah also means being responsible for carrying out a mandate given to someone. Conversely, the nature of trust is treasonous or not executed properly it will result in a lot of badness. Examples of trustworthiness, a) keeping secrets (personal, family, organizational, state secrets) then the confidential information is a form of trust. b) Take good care of yourself (health, family, work, property). c) Protecting the rights of others (deposits), keeping them well and handing them over to the rightful person is a form of implementing a mandate. d) Promises must be kept, because promises we have owed to fulfill these promises, so people who stick to their promises are considered the best behavior. Many people easily make promises but are not trustworthy. Likewise, in folklore stories with story ideas or themes about firmly holding on to promises and trust.

Value can be said as something that is valuable, quality, shows quality and is useful for humans. Something that has value means that something is valuable or useful for human life.

According to Mulyana (2004: 8-9) sees value as a price attached to the culture of society such as language, habits, beliefs, laws, and forms of social organization developed by humans. He further elaborated on four definitions of value, namely: a) Mandate is a belief that makes a person act on the basis of his choice. b) The mandate is a normative standard that influences humans in determining their choice between alternative ways of action. c) Mandate as value is the address of a word yes (value is address of a yes) or contextually, value is something that is indicated by the word yes, d) Mandate as value is a conception (either implied or expressed, which distinguishes individuals or characteristics group) of what is desired, which influences the choice of means, intermediate goals, and ultimate goals of action. Endraswara in amri (2021) describes: a) born from an innocent society, not yet literate, and traditional; b) describe a culture belonging to a particular collective, whose creators are not clear; c) more emphasis on the imaginary aspect, there are satire, humor, and educational messages; and d) often depicts certain collective traditions.

In line with the above opinion, Sugono (2005:111) explains value as a mandate contained in a work, among others: a) Value as hedonic (hedonic value), namely value that can provide direct pleasure to the reader. b) Artistic value, namely the value that can manifest an art or skill in doing a job. c) Cultural values, namely values that can provide or contain a deep relationship with a society, civilization, or culture. d) Ethical, moral, religious values (ethical, moral, religious values), namely values that can provide or transmit advice or teachings related to ethics, morals, and religion. e) Practical value (practical value), namely values that contain practical things that can be applied in real everyday life.

Ibrahim in Amri (2021) suggests that the mandate is a solution to the theme. In the mandate, the views of life and ideals are explicit (overt) and can also be implicit (implied).

In fact, there is a message that seems very vague. The same opinion was expressed by

Kridalaksana (2001:11) that the mandate is the overall meaning or content of a discourse; concepts and feelings that the speaker wants to convey to be understood and accepted by the listener. Esten (1982: 91) defines the mandate as a solution and a solution given by the author in a literary work to the proposed theme. The mandate is a solution to the problems contained in the theme. 
Folklore belongs to the ethnic community which provides a clear picture of the value system as a mandate as an abstraction of a view from various experiences about the value of

Folklore, which can describe things that are praised so that they become persistent role models that are still upheld. Romadi (1993:4-11) wisdom will produce noble values and norms

for the benefit of living together. At the implementation stage, wisdom will direct the application of these values and norms in the form of correct behavior, not distort or distort these values or norms for individual interests.

\section{Research Methods}

Qualitative methodology as a research procedure with results in the form of descriptive data that can be observed through the subject itself (Bogdan and Taylor, 1992:21).

The qualitative descriptive research methodology using primary data sources is the folklore written by Sukapiring (1993) entitled: The folklore of Lisan Karo taken as many as 10 titles and secondary data in the form of reference books, journals and several previous studies, data analysis using the analysis technique of Miles and Huberman (2007:20) includes text data collection, data presentation, and drawing conclusions or verification. Based on the study of Ecolinguistics and the study of Barthes' values. This research was conducted with a qualitative descriptive approach. Moleong (2010: 5) states that qualitative research is research that produces analytical procedures that do not use statistical analysis procedures or other quantification methods. Qualitative research methods are often called naturalistic research methods because the research is carried out in natural conditions (natural setting); also referred to as the ethnographic method, because initially this method was more widely used for research in the field of cultural anthropology; referred to as a qualitative method, because the data collected and the analysis are more qualitative in nature (Sugiyono, 2013: 8).

\section{Result and Discussion}

The Form of Mandate in Folklore

The form of educational value in folklore as an ideal form of value, value is always associated with things that are educational in society as a Karo indigenous and cultural community. The form of educational value in folklore is determined by the value implied as a mandate in the form of advice that influences the mindset of the reader or listener in seeing good and bad, right and wrong in social life. The form of educational value can be revealed intensely because that value is an object of reflection in hacking the form of local wisdom values that are culture-biased and then has an impact on the behavior of cultural communities that make educational values have a function to educate.

The form of educational values in folklore stories can educate in taking lessons as well as role models that are worthy of being guided and then used as examples of bad and bad behavior not to be imitated. So that the function of folklore in educating the public in judging good-bad, right-wrong values, and beautiful-ugly values will be described more clearly as

follows:

\subsection{Message to Forgive}

Forgiving his sister for violating the advice of her parents and brother, not to leave their nest if they want to be safe, was finally violated by her sister's 'ring ganjang penura' by attaching the bird's beak to the tuldak fruit. Then his brother helped by removing the tuldak fruit, but Perukuren put his beak into his sister's mouth and poked it little by little until it was gone. After that, he was given a drink so that Ganjang Penura became fresh again, see the following sentence: 
Accompanied by the rice field snake, go to Stay Perukuren to the intended place.

There he found his sister strangled by a tuldak fruit. To get the tuldak fruit out, Fixed

Perukuren put his beak into his sister's mouth and poked it little by little until it was gone. After that, he was given a drink so Ganjang Penura became fresh again. (D 10/ P 7/ K 2.3).

The character in the folklore which is used as the title of Milo-ilo as a forgiving person because of his promise to marry the king of milo-ilo with his first and second children, but that promise could not be kept because his uncle's son married someone else ilo even married earlier, but even so did not reduce the enthusiasm for work. Her uncle persuaded her not to be disappointed with her daughter's behavior and promised to give her a second daughter as

Milo-ilo's partner, see the text below:

Then it turned out that the eldest daughter of her uncle was married to another young man, not to the king of Milo-ilo. Her uncle persuaded her not to be disappointed by her daughter's behavior and promised to give her a second daughter as Milo-ilo's partner. (D 7/

$\mathrm{P} 3 / \mathrm{K} 1,2)$

Likewise, his uncle's second daughter also married another man, as his brother did, and this was repeated by his sister. He also ended up marrying another man, not Milo-ilo even though he remained patient, he assumed it was the will of the Almighty, said Milo-ilo patiently.

See the text below:

However, what his brother did, was repeated by this younger brother. In the end, she married another man, not Milo-ilo. Milo-ilo answered that it was all by God's will and it was not his meeting to marry the girl of his uncle's daughter. However, Milo-ilo's obedience and loyalty did not diminish because of that incident. (D7, P3/ K 5, 7, and 8)

The character in the Milo-ilo folklore as a forgiving person because of his promise to marry the king of Milo-ilo to his first child, but that promise could not be kept because his uncle's son married someone else, as well as promised to be married to his uncle's second son, but even then it did not happen because the second daughter of her uncle was actually married to another man. Milo-ilo still forgave his uncle and his uncle's two daughters he said that it was the will of the Almighty. Forgiving others is a commendable act because it can create a peaceful life for both those who forgive and those who are forgiven.

\subsection{Obedience to Parents}

The people of the Karo area in general include people who are obedient to both parents, as well as to those who are elders. The Karo people have sensitivity in respecting their parents so that their sentences are biased towards politeness to parents. The Karo people

appreciate parents who have cared for, looked after, nurtured, and educated us from childhood to adulthood. Children's obedience to the Karo tribe to their parents is quite good, this is reflected in the educational values in the folklore of the Karo tribe. This is in the folklore entitled, "Manuk Si Nanggur Dawa".

Based on the results of the analysis on the folklore script in the folklore sentence entitled "Manuk Si Nanggur Dawa" it can be seen in the following sentence:

Mr. Banua Koling answered that, he can't do anything if his father doesn't help him. (D 2/ P 21/ K 1) Ayam Si Nanggur Dawa about the need for an empress for Tuan Banua Koling, to which he replied that it was up to his parents. (D 2. P 22/ K 2)

In Karo folklore, children's appreciation for both parents is manifested in sentences that show obedience to both parents. The folklore of the Karo tribe is biased towards politeness of speech to parents in the form of obedience to both parents.

\subsection{Mandates Can Keep Promises}

In the folklore of the Karo area, a character is found who cannot keep his promise, so that the promise that has been made is finally broken, the impact is that the promise holder 
gets a reply from the inaccuracy of keeping the promise. Illustrated through the character Datu Kandibata who had made a promise then he broke it in the folklore: Guru Kandibata (D

4) and the Fable entitled: Cingcing Ganjang Penura (D10). Likewise, Guru Kandibata's wife, who had missed her child because of pursuing Treasure as a promise to treat the King and the people of Alas who were suffering from a smallpox epidemic, so that the souls and hearts of their two children were taken by Sacred Sibayak, namely: The Sacred Markungklung stone and

the Sacred Emala stone, so that Guru Kandibata's wife promised not to hug her child's shadow, because if she broke her promise they would never meet again, the expression was conveyed in the text:

"Seeing the appearance of the two children, they couldn't wait anymore, then he hugged them both the child, then the tent fell, nothing was left, only the food remained, not one bit less. Apparently no longer visible, only the sound is heard. Guru Kandibata and his

wife promised to comply with those requirements. However, when the two of Guru saw the appearance of their two children, the two Guru impatiently hugged the two children. Suddenly the appearance of the two children disappeared." (D 4/ P 25/ K 5, 6, 7, and 8) Likewise, the result is that when the mother cannot meet, let alone hug her child, it is because the mother is unable to keep her promise, in the end, her child's image has disappeared, which is expressed in the sentence:

"Come on, Mom, come on, Dad, you go home, we're going home too, what can we do. This is an example to humans, because they don't care about money chasing sick children." (D 4/ P 26/ K 1)

Finally, the regret of the mother that was left behind when her child disappeared in front of her, she also shouted for her son with the sentence:

"Where are you my son, come here so we can talk." Nothing was heard anymore. So, Ibu Tandang Karo threw herself, then screamed, saying, "My son Beru Tandang Karo, my son Beru Tandang Karo, I don't know if I'll just kill myself. can we meet." (D 4/ P 26/ K 2, 3, 4, 5 , and 6)

Tempted by the sacred promise of Mount Sibayak, namely the sacred markungklung stone and sacred emala stone.

"Because he was after money. Everyone who called him, that's the money he gave, I don't know how much money he has earned as wages for treating people, we don't know that he forgot to see us can bring it back to life, Finally, said the Beru Tandang Karo, 'Then you say Aunt is fine. You are now what we consider as our parents.' So, they went to the Sacred Mount Sibayak." (D4. P14/ K12, 13, 14)

Likewise, the consequences were borne by Ganjang Penura who could not keep his promise to his mother's advice to survive in the nest and its surroundings because it was the safest place for them. However, Ganjang Penura failed to take his mother and brother's advice, finally Picala Boang's sweet promise to take care of him and take him He saw the beach, but because he was ashamed to have small friends, he finally left Ganjang Penura, which is revealed in Karo's Fable entitled: "Cingcing Ganjang Penura" because he could not

keep his promise, he was finally abandoned by Picala Boang, which is expressed in the following sentence:

"Embarrassed to see Ganjang Penura being so small compared to other animals, Picala Boang left the worms behind." (D 10/ P 5/ K 1)

In Karo folklore, characters who cannot keep promises are found, namely: Guru Kadibata's wife, Guru Kadi Bata, Cingcing Ganjang Penura, and Picala Boang as human and animal figures, namely birds in Karo's fable who have broken their promises. As a result of breaking the promise will get a reward for not keeping the promise. The bias of the mandate given to the folklore characters provides a valuable lesson so that we should keep our promises and do not easily make promises if they cannot be fulfilled.

The value of education as a cultural character bias of the Karo people who must keep 
promises so that the value of education as a bias in folklore reflects the Karo people as an ethnic society who is very obedient to their promises.

4.4 The Mandate to be Patient

Patience in folklore characters from the Karo area can provide valuable lessons through the folklore of Si Aji Bonar as a character who is patient and not lazy at work. The mandate to be patient with the characters becomes a valuable lesson by leaving his lazy nature and becoming a child who is diligent in working, obedient to his parents, and being able to be responsible for his own life and to his parents. Likewise, his mother forced him to live there. Gradually he got used to this situation. The fear disappeared, the poor woman lived a life of eating fruits and leaves, it is in the following sentence:

"He was forced to live there. Gradually she got used to "the situation. The fear was gone, the poor woman lived a life of eating fruit and leaves." (D 1/ P 6/ K 2 and 3)

Patience in the face of various trials experienced by restraining oneself to be steadfast in living a life with full responsibility or patience in facing suffering until she gave birth to a healthy and handsome boy in the middle of the big forest, she lived with suffering until finally a child was born in the middle of the big forest. the content. Data analysis in the sentences

below:

"Suffering until finally a child was born in her womb. The woman gave birth to a son who was healthy and handsome, his face In the middle of the big forest, he lived a life of suffering until finally the child was born in his womb. The woman gave birth to a son who was healthy and handsome, his face. (D 1/ P 7/ K 1 and 2)

Patience with folklore characters from the Karo area can provide valuable lessons through the folklore of Si Aji Bonar and Merga Purba as characters who are patiently abandoned by their families. The value of the character's patience becomes a valuable lesson in life for oneself and for parents. The ethnic bias of the Karo people are persistent and patient in facing various trials of life.

4.5 The Mandate not to be Arrogant The folklore of the Karo region chooses the theme of the character's arrogance towards his superiority and supernatural powers which makes him arrogant with the ability to revive the dead, even though it is only a bone the size of a comb, so it will be resurrected. Folklore entitled: Guru Kandibata. Guru Kandibata as a figure who with supernatural powers can cure any disease, who becomes oblivious to the treasures obtained from curing smallpox that is endemic in the Tanah Alas area. It is analyzed from the sentences in the following text:

"So, he ordered his disciple to summon the messenger of king Alas to his hermitage.

So talk to them. Said Datu Kandibata, "Before you came, I knew that smallpox was now ravaging Tanah Alas. The disease came from the land of Singkel, like the sound of the wind blowing." "That's right Datu," said the messenger of the king of Alas." (D 4/ P 5/ K 2 and 3)

Guru Kandibata as a supernatural figure who became arrogant with his ability to bring the dead back to life he uttered the sentence "I can bring back everyone who died, he said" arrogantly and over and over again, until he forgot himself because of the treasure he got from the King of the Land of Alas. Even Guru Kandibata's wife reminded him with the sentence:

"We don't have time to be embarrassed later, our child will die because we chase money to

Tanah Alas." analyzed through the sentences in the folklore text below:

"That's right, after we arrive in Tanah Alas there will be smallpox from Tanah Alas to

Tanah Karo. Our children will also be affected and it is dangerous too. Even so, don't be afraid because I can bring everyone who dies back to life," he said to his wife. " (D 4/ P 6/ K

5 and 6$)$ 
"I'm very scared, but it's up to you, as long as we don't get embarrassed later, our child will die because we chased money to Tanah Alas." (D 4/ P 5/ K 7) "Don't be afraid, even the dead can be brought back to life," he said. (D 4/ P 6/ K 8)

Likewise, when his two children begged that Guru Kandibata and his wife did not have to leave because he felt this was their last meeting, the two children said while crying. Guru Kandibata arrogantly replied: "I, Datu Besar, your mother is also the great datu of my son, what are you afraid of... no one dares to do evil to you, let alone humans, animals in the forest, even sacred ghosts are afraid to see us." That's the sentence that came out of Guru Kandibata, Guru Kandibata's sentence in the following folklore text:

"Come here Father, I don't know if this is our last meeting mother," said the two children, crying. "Me, Datu Besar, your mother is also my son's great datu, what are you afraid of, even though we go to Tanah Alas, no one dares to do evil to you, let alone humans, animals in the forest, even sacred ghosts are afraid to see us." (D 4/ P 8/ K3) Folklore takes the theme of arrogant behavior in the folklore of the Karo area not only in the folktale entitled, Guru Kandibata, but also in the folktale entitled: Telagah Pitu di Sarinembah. The arrogant figure is Guru Pakpak who wants to try the humble Guru Diden, Guru Pakpak deliberately wants to challenge Guru Diden even though his humility and hospitality has been misinterpreted by Guru Pakpak. Guru pakpak still wants to conquer Guru Diden. Guru Pakpak's arrogance who wants to complain about Guru Diden's supernatural powers. It is analyzed from the sentences in the following text:

The test by the seven Guru from Pakpak had been prepared by Guru Diden by preparing a hole filled with chicken eggs, cimpa cakes, and others. Please put your hand in it, said Guru Diden in testing the seven Guru from Pakpak, it can be seen in the following paragraph:

"That's where the seven people from Pakpak tested, who had been prepared by Guru Diden. "Here there is a hole that contains chicken eggs, cimpa cakes, etc. Please put the brother's hand in it," said Guru Diden. (D 6/ P 8/ K 1, 2, and 3)

But Guru Pakpak's arrogance to Guru Diden was repaid by the host with a humble and friendly attitude. Host Master Diden and his wife are still serving guests well. In the following paragraph:

"Guru Pakpak then put his hand into the hole, just like the experience of his six friends, his hand was caught in the hole. Not long after, seven springs appeared on the bank of a large river not far from the scene. Each spring is accommodated by a lake. By the people around Sarinembah and Raja Tengah and other villages from the seven Gurus, Sir, who wanted to try Guru Diden's skills. Until now, on a good day and a moonlit night, from the seven springs the water can be seen running high, giving rise to an attractive sight." (Sukapiring et al, 1993:118-121) (D 6/ P 15/ K 1, 2, and 3)

The message that can be learned from the folklore above is the arrogance of the characters in the Guru Kandibata folklore and the characters in Telagah Pitu Sarinembah. The arrogant figures in the folklore above are Guru Kandibata who is able to bring the dead back to life and can treat all diseases and the Seventh Guru Pakpak who wants to try the humble Guru Diden. In fact, even though Guru Diden was tested, his humility and hospitality had been misinterpreted by Guru Pakpak. The mandate of the Karo folklore is as a characteristic of the Karo people who are not arrogant, the Karo people are generally humble and not arrogant about what they have.

4.6 Message for Humility The theme of the Karo regional folklore entitled: Telagah Pitu di Sarinembah with the humble Guru Diden was challenged by the seven Pakpak Gurus who deliberately wanted to challenge Guru Diden. But Guru Diden still showed his humble and friendly nature and attitude which was misunderstood by Guru Pakpak. Guru Pakpak arrogantly wants to 
complain about Guru Diden's supernatural powers. The folklore above, on the other hand, in this section examines the humble value of the character in the folklore of the Karo area.

The folklore of the Karo area can be used as an example for a character who is humble and friendly to everyone, even though that person really wants to test his magic with the host. it can be seen in the paragraph below:

"That night before going to bed, Guru Diden's wife asked her guest. Guru Pakpak explained their origins, as well as the purpose and purpose of their journey so far." (D 6/ P 8/

$\mathrm{K} 3,7,8$, and 9)

Guru Diden's humble attitude with a good attitude still respects other people after being tested by testing Guru Diden's supernatural powers, Guru Diden still provides good service to Guru Diden. To provide chicken eggs, chip cookies, etc. in the hole. This attitude can be used as an example through a character who is humble and friendly to everyone, it can be seen in the paragraph below:

"That's where the seven people from Pakpak tested, who had been prepared by Guru Diden. "Here there is a hole that contains chicken eggs, cimpa cakes, etc. Please put the brother's hand in it," said Guru Diden. (D 6/ P 8/ K 1, 2, and 3)

Iktibar that can be learned through folklore through the arrogance of the characters in the folklore of Telagah Pitu Sarinembah. The humble Guru Diden, although tested but still with humility and hospitality. The folklore of the Karo area is a characteristic of the Karo people who are friendly, the Karo are generally humble and not arrogant about what they have. Folklore is a reflection of the Karo people who are humble and not arrogant.

\section{Conclusion}

The folklore of the Karo region as one of the ethnic cultures that reflects the characteristics of the Karo ethnic community that still exists today. Ethnic folklore provides an overview of the life of ethnic communities that teach moral values, norms and social values, educational values, religious values, ethics, and cultural values in everyday life. Folklore teaches various manifestations of values that can be used as literacy materials that can be used as descriptions of ethnic characteristics as forms of educational values.

The form of the mandate as values in folklore stories can educate in taking lessons as well as role models that are worthy of being guided and then used as examples of bad and bad behavior not to be imitated like a mother's love for her child who sincerely and selflessly forgives her child. The mandate as a value in Karo folklore is biased such as: a) the mandate to forgive, b) the mandate to obey parents, c) the mandate to keep promises, d) the mandate to be patient, e) the mandate not to be arrogant and arrogant, f) the mandate to be humble. Lessons for the reader to be wise to admit mistakes. The value of education as a cultural character bias of the Karo people who are wise to admit mistakes and be brave.

\section{References}

Amri, Yusni Khairul. 2020. Cerita rakyat Etnik: Kearifan Lokal Etnik sebagai Bias Nilai Budaya pada Cerita rakyat, Budapest International Research and Critics University (BIRCUPublishing): Medan

Amri, Yusni Khairul. 2021. Bittot Van De Longas' Indiscriminate as a Message of Angkola Culture. Budapest International Research and Critics Institute-Journal (BIRCI-Journal) Volume 4, No. 4, November 2021, Page: 10539-10546 e-ISSN: 2615-3076 (Online), pISSN: 2615-1715 (Print) Danandjaja, James. 2007 (Cet. VII). Cerita rakyat Indonesia: Ilmu Gosip, Dongeng, dan Lainlain. Jakarta: PT Pustaka Utama Grafiti. Endraswara, S. 2010. Cerita rakyat Jawa : Macam, Bentuk dan Nilainya. Jakarta: Penaku. 
Endraswara, Suwardi. 2003. Metodologi Penelitian Sastra: Epistemologi, Mode, Teori, dan Aplikasi. Yogyakarta: Pustaka Widyatama.

Esten, Mursal. 1982. Sastra Lisan dan Tradisi Subkultur. Bandung: Angkasa Bandung. Ibrahim, Abdul Syukur. 1987. Kesusastraan Indonesia Sajian Latih-Ajar Mandiri. Surabaya: Usaha Nasional.

Jumadi, dkk. 1996. Tema dan Amanat Dongeng Banjar. Jakarta: Pusat Pembinaan dan Pengembangan Bahasa, Departemen Pendidikan dan Kebudayaan. Kridalaksana, Harimurti. 2001. Kamus Linguistik. Jakarta: Gramedia Pustaka Utama. Mulyana, A dan Gunawan, R, 2004. "Lingkungan Terdekat; Sumber Belajar Sejarah Lokal", dalam

Mulyana, Gunawan 2007. Sejarah Lokal: Penulisan dan Pembelajaran di Sekolah. Bandung: Salamina Press. Kartodirdjo, A. Sartono. 1986. „Suatu Tinjauan Fenomenologis tentang Cerita rakyat Karo “e Cerita rakyat Karo. (Ed. Soedarsono). Yogyakarta: Proyek Penelitian dan Pengkajian Kebudayaan Nusantara (Javanologi), Direktorat Jenderal Kebudayaan, Departemen Pendidikan dan Kebudayaan.

Sukapiring, Peraturen dkk 1993. Cerita rakyat Lisan Karo. Departemen Pendidikan dan Kebudayaan: Jakarta.

Sugono, Dendy. (ed.). 2005. Buku Praktis Bahasa Indonesia Jilid 2. Jakarta: Pusat Bahasa Departemen Pendidikan Nasional. Wikipedia. 2010. Cerita Rakyat. Dalam http://en.wikipedia.org/wiki/CeritaRakyat, Diakses pada tanggal 06 Februari 2010.

Romadi dan Ganda Febri Kuniawan, Pembelajaran Sejarah Lokal.... 93 Cerita rakyat UPI: http:/ /berita.upi.edu/2012/07/17/pidato-prof-dr-dadang- supardan-padapengukuhan-sebagai-guru-besar-upi- selasa-1772012/). 